\title{
ARAŞTIRMA / RESEARCH \\ Comparison of energy consumptions measured by metabolic monitor with standard equations in intensive care patients
}

Yoğun bakım hastalarında metabolik monitör ile ölçülen enerji tüketiminin standart denklemlerle karşılaştırılması

Emre Karakoç1 1 , Onur Taktakoğlu²

${ }^{1}$ Çukurova Üniversitesi Tıp Fakültesi, İç Hastalıkları Yoğun Bakım Bilim Dalı, Adana, Turkey

${ }^{2}$ Altın Koza Hastanesi, İç Hastalıkları Kliniği, Adana, Turkey

${ }^{3}$ Adana Şehir Hastanesi, İç Hastalıkları Kliniği, Yoğun Bakım Kliniği, Adana, Turkey

\begin{abstract}
Cukurova Medical Journal 2021;46(2):589-600
Abstract

Purpose: The aim of this study was to determine parameters affecting the energy consumption in intensive care patients, and the most reliable formulas for calculation of energy consumption.

Materials and Methods: This prospective study was carried out in the intensive care unit of the Internal Medicine Department of Çukurova University Hospital. Total 71 patients above 18 years of age, with hemodynamical and respirational stability, and being followed up on a mechanical ventilator for more than 24 hours, were included to this study. We analyzed the correlation of calculated energy consumption values obtained from formulas, with the energy consumption values measured by indirect calorimeter.

Results: The study was executed on 71 patients. The mean energy consumption of the patients was $2078 \pm 794$ $\mathrm{kcal}$ and the mean energy need per kilogram was found as $31.64 \pm 13.82 \mathrm{kcal}$. Indirect calorimeter measurements showed the strongest correlation with Swinamer formula. Conclusion: Indirect calorimetry has become not only a "gold standard" but an "achievable gold standard" in determining energy consumption. We recommend that the indirect calorimeter method should be used in intensive care patients to maintain nutrition properly. Under conditions where indirect calorimeter cannot be used, or it is not desirable to wait for 24 hours; feeding can be started

\section{Öz}

Amaç: $\mathrm{Bu}$ çalışmda yoğun bakım hastalarında enerji tüketimini etkileyen parametreleri ve enerji tüketiminin hesaplanması için en güvenilir formüllerin belirlenmesi amaçlanmıştır.

Gereç ve Yöntem: Bu prospektif çalışma Çukurova Üniversitesi Hastanesi İç Hastalıkları Anabilim Dalı yoğun bakım ünitesinde yapıldı. Çalışmaya, hemodinamik ve solunum stabilitesi olan, mekanik ventilatörde 24 saatten fazla izlenen 18 yaş üstü toplam 71 hasta dahil edildi. Formüllerden elde edilen hesaplanan enerji tüketim değerlerinin, indirekt kalorimetre ile ölçülen enerji tüketim değerleri ile korelasyonunu inceledik.

Bulgular: Çalışma 71 hasta üzerinde gerçekleştirildi. Hastaların ortalama enerji tüketimi $2078 \pm 794 \mathrm{kcal}$ ve kilogram başına ortalama enerji ihtiyac $31.64 \pm 13.82 \mathrm{kcal}$ olarak bulundu. İndirekt kalorimetre ölçümleri Swinamer formülü ile en güçlü korelasyonu gösterdi.

Sonuç: İndirekt kalorimetri, enerji tüketiminin belirlenmesinde sadece "altın standart" değil, "ulaşılabilir altın standart" haline geldi. Yoğun bakım hastalarında beslenmenin doğru șekilde sürdürülmesi için indirekt kalorimetre yönteminin kullanılmasını öneriyoruz. İndirekt kalorimetrenin kullanılamadığı veya 24 saat beklemenin istenmediği koşullar altında; 2 saatlik bir ölçümün sonuçlarına göre veya güvenilir tahmin denklemlerine göre besleme başlatılabilir.
\end{abstract} according to the results of a 2-hour measurement, or reliable predictive equations.

Keywords: Nutritional support, indirect calorimetry, malnutrition, intensive care unit
Anahtar kelimeler: Beslenme desteği, indirekt kalorimetre, yetersiz beslenme, yoğun bakım ünitesi

Yazışma Adresi/Address for Correspondence: Dr. Murat Erdogan, Adana Şehir Hastanesi, İç Hastalıkları Kliniği, Adana, Turkey E- mail: drmuraterdogan83@gmail.com

Geliş tarihi/Received: 22.01.2021 Kabul tarihi/Accepted: 15.04.2021 Çevrimiçi yayın/Published online: 20.05.2021 


\section{INTRODUCTION}

Malnutrition is a common problem in intensive care patients ${ }^{1,2}$. In intensive care patients, malnutrition is associated with various problems such as prolonged hospitalization and increased healthcare costs in patients ${ }^{3,4}$. Underestimation of energy need may lead to disruption of the tissue functions and repair capability, and immune system. It may also prolong the length of hospitalization or post-op follow-up period, significantly ${ }^{3,5,6}$. Calculating energy consumption more than the needs of patients, or feeding patients more than they need may also cause various problems. Complications of over feeding, including prolonged stay in the mechanical ventilator, hyperglycemia, hepatic dysfunction, delayed surgical wound healing, suture and anastomosis complications, hyperosmolar condition, azotemia, difficulty weaning, and immune system disorders have been reported ${ }^{7,8}$.

Energy consumption can be measured by direct and indirect calorimetry, as well as calculated by various formulas. The indirect calorimetry method has been accepted as the gold standard in determination of energy consumption?. Despite its status as the gold standard, indirect calorimetry is not yet widely used due to the long measurement time, its standardization problems and lack of coverage by some health insurances ${ }^{10}$. Therefore, standard (predictive) formulas are frequently used in clinics for the prediction of energy consumption. However, these formulas were created by the studies on healthy people. Therefore, it is thought that these calculations may be wrong in patients, whose energy needs are significantly increase (e.g. intensive care patients). Only a few formulas have been studied on patients on the ventilator ${ }^{11,12}$. Since the superiority of the formulas cannot be clearly determined in the previous studies, there is not an established consensus on which formula is the most useful ${ }^{2}$.

In our study, we compared the energy consumptions measured by indirect calorimetry (metabolic monitor) and calculated by standard formulas. We made our measurements and calculation in intensive care patients, who were intubated and followed on mechanical ventilator. We aimed to determine which parameters will affect the energy consumption in intensive care patients, and which formula is the most reliable among the current energy consumption measurement formulas.

\section{MATERIALS AND METHODS}

This prospective study was carried out in the intensive care unit (ICU) of the Internal Medicine Department of a university hospital, between 20132014. Approval for the study was granted by the Local Ethics Committee of Çukurova University Medicine Faculty (decision no: 27, dated: 03/01/2014). Informed consent was obtained from all patients or their legal guardians.

After the permission of the ethics committee, 71 patients above 18 years of age, with hemodynamical and respirational stability, and being followed up on a mechanical ventilator for more than 24 hours, were included to this study. The patients who had respiratory quotient (RQ) values outside the physiological limits, received more than 0.25 $\mathrm{mcg} / \mathrm{kg} / \mathrm{min}$ of noradrenaline or $20 \mathrm{mcg} / \mathrm{kg} / \mathrm{min}$ of dopamine, without 24 hours of measurement due to extubation or death, had pneumonectomy, or had fractional inspired oxygen $(\mathrm{Fi} 02) \geq 55 \%$, positive end expiratory pressure (PEEP) $\geq 20$ mbar, respiratory rate $\geq 35 /$ minute during admission or follow-up, were excluded. Of patients, 21 were excluded from the study due to death and 18 were excluded because of extubation. Furthermore, 12 patients were set to $\mathrm{FiO} 2>60 \%$ or respiratory rate $\geq 35 /$ minute during measurement, and were excluded from this study. Of patients, 7 were excluded due to their RQ rate outside physiological limits $(<0.7$ or $>1.3)$. Finally, 2 patients were excluded from the study because of the insertion of a thorax tube.

\section{Measurements and calculations}

Patients were inhaled under pressure or volume control, consistent with the cause of respiratory failure. Indirect calorimeter measurements were made with the E-COVX module with DatexOhmeda gas technology, which was attached to GE Carescape $^{\mathrm{TM}}$ modular monitors for 24 hours continuously, following the stabilization of patients after connection to the ventilator. The naming of the modules is done in line with the measured parameters, namely "C" for end-tidal carbon dioxide (EtCO2), fractional inspired carbon dioxide (FiCO2) and nitrous oxide (N2O); "O" for FiO2, end-tidal oxygen (EtO2) and FiO2 / EtO2 difference; "V" for pressure, volumes, current and compliance, resistance; and " $\mathrm{X}$ " for $\mathrm{O}_{2}$ consumption $\left(\mathrm{VO}_{2}\right)$ and carbon dioxide production (VCO2). 
Measurement of energy consumption values in 2nd, 6th, 12th and 24th hours were recorded. All patients were measured by the same researcher according to the manufacturer's recommendations. During the measurement, there was no air leakage from the circuits except for the cases of obstruction and shortterm tracheal aspiration attempts in the sampling tube.

Routine nursing care such as daily body care and position changes were performed in accordance with the general treatment principles. Age, height, body weight, ideal weight, body surface area (BSI) and body mass index (BMI) of patients, malnutrition status at the time of application according to British Association for Parenteral and Enteral Nutrition (BAPEN) malnutrition scale, type of nutrition, acute physiology and chronic health evaluation 2 (APACHE II) score within 24 hours of measurement, the sequential organ failure assessment (SOFA) and simplified acute physiology score 2 (SAPS II) scores, admission categories, energy consumptions in $2^{\text {nd }}, 6^{\text {th }}, 12^{\text {th }}$, and $24^{\text {th }}$ hours (in kcal), $\mathrm{RQ}, \mathrm{VCO}_{2}, \mathrm{VO}_{2}$ values, body temperature, minute ventilation, tidal volume, and breathing frequency were recorded ${ }^{13-16}$. At the time of admission; lactate, albumin, procalcitonin, brain natriuretic peptide (BNP), blood urea nitrogen (BUN), creatinine $(\mathrm{Cr})$, magnesium $(\mathrm{Mg})$, phosphate $(\mathrm{P})$, neutrophil and lymphocyte percentages, and white blood cell count (WBC), hemoglobin ( $\mathrm{Hgb})$, hematocrit (Htc), platelet (Plt), mean platelet volume (MPV), red cell distribution width (RDW) and mean corpuscular volume (MCV) values were recorded.

All patients underwent sedation with fentanylpropofol or fentanyl-midazolam with a Riker sedation score of 2-3 to adapt to the ventilator. After the clinical evaluation, nutritional support was provided by choosing the most appropriate way based on the European Society for Clinical Nutrition and Metabolism (ESPEN) intensive care nutrition guide. The amount of targeted calorie of nutritional support was achieved in three days ${ }^{17}$. Total parenteral nutrition was performed with ready-made commercial products or mixer prepared solutions, according to the patient's needs via a central catheter. For enteral feeding, ready-made standard commercial products $(1 \mathrm{ml} / 1 \mathrm{kcal})$ were delivered by nasogastric or nasojejunal tubes. Heights of patients were measured in the supine position. Body weights were measured and recorded using weight-measuring beds, after calibration. Patients were classified as underweight (BMI <19), normal weight $(\mathrm{BMI}=19$ to 24.9), overweight (BMI 25 to 29.9) and obese (BMI $\geq 30$ ) according to their BMI values. In the weight calculation, Devine and Robinson formulas were used for men and women, respectively ${ }^{13,14}$. After obtaining of all parameters, energy consumption was calculated with Harris-Benedict, Owen, Mifflin - St Joir 1990, Obesity, Ireton-Jones specific to 1992 and 1997, Penn-State specific to 1998-2003 and 2010, Swinamer 1990, Brandi 1999, Faisy and Schofield 2003 formulas by using ideal and measured weights. Energy consumption values measured at the $2 \mathrm{nd}$, 6th and 12th hours were compared with 24-hour measurements, by using Pearson correlation and Bland Altman analysis ${ }^{18}$. We also aimed to analyze the compliance of values obtained through formulas, with the energy consumption measured by an indirect calorimeter (measured energy consumption-MEC), by using Pearson correlation and Bland-Altman analysis.

Since "malnutrition" and "overfeeding" can be observed in patients, who received feeding according to the calculated energy consumption by using the predictive equations, the adequacy of these calculations was examined. Values obtained from standard formulas (calculated energy consumptionCEC) were divided by the MEC, and percentage values were presented. As stated in the previous literature, these ratios were divided into 3 groups, namely a ratio less than $<80 \%$ was considered as "inadequate", ratios between $80 \%$ and $110 \%$ were considered "sufficient", a ratio more than $<110 \%$ was considered as "high"19.

Another research topic for our study was to evaluate the relationship between disease severity and energy consumption. Due to the multiple factors capable to affect energy consumption, the energy consumption for unit surface in patients was calculated by dividing the measured 24-hour average energy consumption value by BMI and BSA values. Then, these values were compared with APACHE II, SAPS II and SOFA scores, by using Pearson correlation.

\section{Statistical analysis}

Statistical analyzes were performed by using SPSS (version 18.0.0, July 30th 2009, SPSS Inc. Chicago. IL). The compliance of the CEC values with the MEC values was evaluated by Bland-Altman analysis. For Pearson correlation, a $\mathrm{p}$ value of $<0.05$ was considered statistically significant. For Bland-Altman analysis, a $\mathrm{p}$ value of $<0.001$ was considered 
statistically significant. Frequencies of CEC:MEC ratio groups, namely $<80 \%, 80-110 \%,>110 \%$, were presented. Continuous variables were presented as mean \pm standard deviation (SD).

\section{RESULTS}

The study was executed on 71 patients. Of these patients, $n=26(36.3 \%)$ were female, $n=45(63.4 \%)$ were male. Patients were aged between 19 and 88, with a mean age of $60.35 \pm 18.00$. The mean body mass index value was calculated as $24.25 \pm 5.09$ $\mathrm{kg} / \mathrm{m} 2$, ranging between 13.60 and $45 \mathrm{~kg} / \mathrm{m}^{2}$. The mean body surface area of patients was found as $1.76 \pm 0.22$, ranging between $1,38-2,35 \mathrm{~m}^{2}$. The mean APACHE II, SOFA and SAPS II scores were calculated as $22.32 \pm 7.44,10.45 \pm 3.79$ and $52.25 \pm 16.93$, respectively (Table 1$)$. The majority of the patients $(\mathrm{n}=41 ; 57.7 \%)$ received parenteral nutrition, and a large fraction of the patients $(n=43$; 60.6) had malnutrition. Furthermore, an important fraction of patents $(n=40,56.3 \%)$ needed vasopressors. The most common reasons for hospitalization were related to either sepsis (without malignancy $n=26 ; 36.6 \%$, and with malignancy $n=17$; $23.9 \%)$ or septic shock $(\mathrm{n}=10 ; 14.1 \%)$ (Table 2$)$.

Table 1. Demographic characteristics and clinical scores of the patients

\begin{tabular}{|l|c|c|}
\hline Characteristic & Mean \pm Standard Deviation & Minimum-Maximum \\
\hline Age $($ year $)$ & $60.35 \pm 18.00$ & $19-88$ \\
\hline Height $(\mathrm{cm})$ & $167.38 \pm 7.68$ & $152-185$ \\
\hline Weight $(\mathrm{kg})$ & $68.28 \pm 16.56$ & $38-130$ \\
\hline BMI $(\mathrm{kg} / \mathrm{m} 2)$ & $24.25 \pm 5.09$ & $13.60-45$ \\
\hline BSA $(\mathrm{m} 2)$ & $1.76 \pm 0.22$ & $1.38-2.35$ \\
\hline APACHE II & $22.32 \pm 7.44$ & $6-38$ \\
\hline SOFA & $10.45 \pm 3.79$ & $3-18$ \\
\hline SAPS II & $52.25 \pm 16.93$ & $15-99$ \\
\hline
\end{tabular}

BMI: Body mass index, BSA: Body surface area, APACHE II: Acute Physiology and Chronic Health Evaluation 2, SOFA: The Sequential Organ Failure Assessment, SAPS II: Simplified Acute Physiology Score 2.

Table 2. Patients characteristics on nutritional support, malnutrition and hospitalization

\begin{tabular}{|l|l|l|}
\hline Characteristic & n & $\%$ \\
\hline Nutritional support & 30 & 42.3 \\
\hline Enteral & 51 & 57.7 \\
\hline Parenteral & 41 & 60.6 \\
\hline Malnutrition & 43 & 39.4 \\
\hline Present & 28 \\
\hline Absent & \multicolumn{2}{|l|}{} \\
\hline Need for vasopressors & 56.3 \\
\hline Present & 40 & 43.7 \\
\hline Absent & 31 & 36.6 \\
\hline Reason for hospitalization & \multicolumn{2}{|l|}{} \\
\hline Sepsis without malignity & 26 & 23.9 \\
\hline Sepsis with malignity & 17 & 14.1 \\
\hline Septic shock with malignity & 10 & 11.3 \\
\hline Acute renal failure & 8 & 4.2 \\
\hline Amyotrophic Lateral Sclerosis\& Respiratory Failure & 3 \\
\hline Chronical liver disease & 3 & 4.2 \\
\hline Hyponatremia & 2 & 2.8 \\
\hline Thrombotic thrombocytopenic purpura & 1 & 1.4 \\
\hline Peptic Ulcer Perforation & 1 & 1.4 \\
\hline
\end{tabular}

The measured laboratory values of the patients were summarized in Table 3. The mean energy consumption of the patients was measured as $2078 \pm$ $794 \mathrm{kcal}$ and the mean weight was found as $68.28 \pm$ $16.56 \mathrm{~kg}$. The mean energy need per kilogram was calculated as $31.6 \pm 13.82$ kcal. (Table 4) Measurements taken at 2nd, 6th, and 12th hours were compared with 24-hour measurements by using Pearson correlation analysis, and $\mathrm{r}$ values were 0.877 , 0.877 and 0.899 , respectively. The correlation of 
measured energy consumption values obtained from indirect calorimeter measurements, with values derived from standard formulas (calculated energy consumption) was examined. Indirect calorimeter measurements showed the strongest correlation with Swinamer formula (a significant positive moderate correlation, with $\mathrm{p}$ value of $<0.001$, and $\mathrm{r}$ value of $0.510)$, and weak to moderate correlations with the other standard formulas developed for calculation of energy consumption ( $\mathrm{r}$ is ranging from 0.308 to 0.499 , all $\mathrm{p}$ values are $<0.05$ ) (Table 5).

Table 3. Laboratory measurements of patients

\begin{tabular}{|l|c|c|}
\hline Laboratory value & Mean \pm Standard Deviation & Minimum-Maximum \\
\hline${ }^{*}$ Lactate $(\mathrm{mmol} / \mathrm{l})$ & $2.70 \pm 1.56$ & $0.40-8.40$ \\
\hline Procalcitonin $(\mathrm{ng} / \mathrm{dl})$ & $16.43 \pm 27.72$ & $0.01-100$ \\
\hline Albumin $(\mathrm{gr} / \mathrm{dl})$ & $2.24 \pm 0.60$ & $1-4.10$ \\
\hline $\mathrm{BNP}(\mathrm{pg} / \mathrm{ml})$ & $13.837 \pm 13.838$ & $59-35000$ \\
\hline $\mathrm{BUN}(\mathrm{mg} / \mathrm{dl})$ & $41.5 \pm 35.7$ & $3-239$ \\
\hline $\mathrm{Cr}(\mathrm{mg} / \mathrm{dl})$ & $2.0 \pm 41.9$ & $0.13-8.65$ \\
\hline $\mathrm{P}(\mathrm{mg} / \mathrm{dl})$ & $4.6 \pm 1.94$ & $1.40-10.10$ \\
\hline $\mathrm{Mg}(\mathrm{mg} / \mathrm{dl})$ & $2.06 \pm 0.48$ & $1.3-3.69$ \\
\hline $\mathrm{WBC}(\mathrm{x} 1000 / \mathrm{uL})$ & $18.1 \pm 30.8$ & $0.1-252$ \\
\hline $\mathrm{Hgb}(\mathrm{gr} / \mathrm{dl})$ & $9.7 \pm 2.15$ & $3.2-14.9$ \\
\hline $\mathrm{Htc}(\%)$ & $29.48 \pm 6.3$ & $15.5-44.1$ \\
\hline Plt $(x 1000 / \mathrm{uL}):$ & $175 \pm 139$ & $4-534$ \\
\hline
\end{tabular}

BNP: Brain natriuretic peptide, BUN; Blood urea nitrogen, Cr: Creatinine, P: phosphorus, Mg: magnesium, WBC: White blood cell, Hgb: Hemoglobin, Htc: Hematocrit, Plt: Platelet; *Highest value in 24-hour measurement

Table 4. Measured and calculated energy consumption values of patients

\begin{tabular}{|c|c|c|}
\hline Measurement or Calculation & Mean \pm Standard Deviation & Minimum-Maximum \\
\hline Energy in $2 \mathrm{hr}$ (kcal/day) & $2031 \pm 908$ & $438-5959$ \\
\hline Energy in 6hr (kcal/ day) & $2108 \pm 930$ & $647-5978$ \\
\hline Energy in $12 \mathrm{hr}$ (kcal/ day) & $2062 \pm 874$ & $442-5206$ \\
\hline Energy in $24 \mathrm{hr}$ (kcal/ day): & $2078 \pm 794$ & $665-5029$ \\
\hline Harris-Benedict $(\mathrm{M})$ & $1790 \pm 688$ & $657-3474$ \\
\hline Harris-Benedict (I) & $1679 \pm 617$ & $663-2748$ \\
\hline Owen $(\mathrm{M})$ & $1544 \pm 184$ & $1182-2205$ \\
\hline Owen (I) & $1482 \pm 112$ & $1291-1690$ \\
\hline Mifflin- St Joir 1990(M) & $1489 \pm 205$ & $971-2077$ \\
\hline Mifflin- St Joir 1990(I) & $1370 \pm 153$ & $1036-1760$ \\
\hline Ireton-Jones Obezite (M) & $1907 \pm 575$ & $840-2880$ \\
\hline Ireton-Jones Obezite (I) & $1873 \pm 544$ & $841-2759$ \\
\hline Ireton-Jones 1992(M) & $1849 \pm 240$ & $1305-2563$ \\
\hline Ireton-Jones 1992(I) & $1818 \pm 235$ & $1312-2477$ \\
\hline Ireton-Jones $1997(\mathrm{M})$ & $1622 \pm 241$ & $1076-2292$ \\
\hline Ireton-Jones 1997 (I) & $1592 \pm 236$ & $1083-2206$ \\
\hline Schofield (M) & $1571 \pm 245$ & $1049-2364$ \\
\hline Schofield(I) & $1511 \pm 181$ & $1215-1848$ \\
\hline Faisy(M) & $2011 \pm 364$ & $1479-3862$ \\
\hline Faisy(I) & $1962 \pm 328$ & $1500-3731$ \\
\hline Penn-State 1998 & $2161 \pm 833$ & $704-4216$ \\
\hline Penn-State 2003 & $1731 \pm 340$ & $1181-3139$ \\
\hline Penn-State 2010 & $1857 \pm 404$ & $1386-4371$ \\
\hline Brandi & $2343 \pm 758$ & $842-4793$ \\
\hline Swinamer & $1237 \pm 328$ & $615-2517$ \\
\hline
\end{tabular}

M: Calculation with measured weight, I: Calculation with ideal weight 
Table 5. Correlation of energy consumption in 24-hour measurement with energy consumption calculated with measured (M) or ideal (I) weights

\begin{tabular}{|l|c|c|}
\hline Energy consumption formula & $\mathrm{p}$ value & r value \\
\hline Harris-Benedict $(\mathrm{M})$ & $\mathrm{p}<0.001$ & 0.425 \\
\hline Harris-Benedict $(\mathrm{I})$ & $\mathrm{p}=0.001$ & 0.395 \\
\hline Owen $(\mathrm{M})$ & $\mathrm{p}=0.009$ & 0.308 \\
\hline Owen $(\mathrm{I})$ & $\mathrm{p}=0.009$ & 0.310 \\
\hline Mifflin(M) & $\mathrm{p}=0.009$ & 0.308 \\
\hline Mifflin(I) & $\mathrm{p}<0.001$ & 0.415 \\
\hline Ireton-Jones Obezite $(\mathrm{M})$ & $\mathrm{p}<0.001$ & 0.435 \\
\hline Ireton-Jones Obezite $(\mathrm{I})$ & $\mathrm{p}<0.001$ & 0.415 \\
\hline Ireton-Jones 1992(M) & $\mathrm{p}<0.001$ & 0.499 \\
\hline Ireton-Jones 1992 $(\mathrm{I})$ & $\mathrm{p}<0.001$ & 0.464 \\
\hline Ireton-Jones 1997 (M) & $\mathrm{p}<0.001$ & 0.495 \\
\hline Ireton-Jones 1997 (I) & $\mathrm{p}<0.001$ & 0.459 \\
\hline Schofield $(\mathrm{M})$ & $\mathrm{p}=0.003$ & 0.346 \\
\hline Schofield $(\mathrm{I})$ & $\mathrm{p}=0.005$ & 0.327 \\
\hline Faisy $(\mathrm{M})$ & $\mathrm{p}<0.001$ & 0.473 \\
\hline Faisy(I) & $\mathrm{p}<0.001$ & 0.473 \\
\hline Swinamer & $\mathrm{p}<0.001$ & 0.510 \\
\hline Brandi & $\mathrm{p}=0.002$ & 0.362 \\
\hline Penn-State 1998 & $\mathrm{p}<0.001$ & 0.494 \\
\hline Penn-State 2003 & $\mathrm{p}<0.001$ & 0.447 \\
\hline Penn-State 2010 & $\mathrm{p}<0.001$ & 0.484 \\
\hline
\end{tabular}

M: Calculation with measured weight, I: Calculation with ideal weight

The measured and calculated energy consumptions were compared by using the Bland Altman analysis with an average trend and 95\% confidence interval. The mean differences of standard formula were ranged from $-1876 \pm 788$ to $707 \pm 743$ (Table 6). The highest frequency of sufficiency in terms of MEC:CEC ratios was found in Owen formula $(46.5 \%)$, calculated for ideal weight and multiplied with long factor 1.3. Owen formula was closely followed by Mifflin SJ (calculated for ideal weight and multiplied by x 1.3), Ireton Jones 1992 formulas (calculated for measured weight), with sufficiency frequencies of $43.7 \%$ and $43.7 \%$, respectively (Table 7). The energy consumption measured by indirect calorimeter were compared among the groups with and without malnutrition, and there was no significant difference in energy consumption between these groups $(p=0.776, t=0.286)$. Measured energy consumption was correlated with APACHE II, SAPS II and SOFA scores. No correlations were found with significant $(\mathrm{p}=0.875, \mathrm{p}=0.162$ and $\mathrm{p}=0.683$, respectively). Since there may be many factors that may affect the energy consumption, the energy consumption for the unit surface was calculated in each patient, by dividing the measured 24-hour energy consumption value by BMI and BSA values. Obtained values were correlated with APACHE II,
SAPS II and SOFA scores; however, no significant correlation was found ( $p>0.05)$. The diet types (enteral or parenteral) were compared for mean energy consumption, but there was no significant difference among diet types $(\mathrm{p}=0.304, \mathrm{t}=1.035)$.

The mean energy consumptions of patients who received inotropic therapy and those who did not, were compared, and no significant difference was found $(\mathrm{p}=0.596, \mathrm{t}=-0.532)$. The correlations between procalcitonin, albumin, BNP and lactate values at admission, and energy consumption were examined, and these correlations were statistically not significant $(p=0.52, p=0.536, p=0.487, p=0.622$, respectively). In addition, relationships between the white blood cell count, hematocrit and platelet count of the patients at the time of admission, and the MEC were examined. MEC had a moderate correlation with the white blood cell count, but this correlation was statistically not significant $(\mathrm{p}=0.08, \mathrm{r}=0.312)$. MEC value had no significant correlation with hematocrit and platelet values $(\mathrm{p}=0.565$, and $\mathrm{p}=0.396$, respectively). Finally, the correlations between thyroid function tests (TSH, fT4, fT3) and MEC were analyzed, and there was a significant weak negative correlation with TSH $(\mathrm{p}=0.025, \mathrm{r}=-0,267)$ 
Table 6. Bland Altman analysis results for 24-hour energy consumption value and calculated energy consumptions

\begin{tabular}{|c|c|c|c|}
\hline Standard Formula & $\begin{array}{c}\text { Mean Difference } \pm \text { SD } \\
(\text { CI 95\%) }\end{array}$ & $\begin{array}{l}\text { Upper Limit of } \\
\text { Agreement } \\
\text { (CI 95\%) }\end{array}$ & $\begin{array}{l}\text { Lower Limit of } \\
\text { Agreement } \\
\text { (CI 95\%) }\end{array}$ \\
\hline $\mathrm{HB}(\mathrm{M})$ & $287 \pm 799$ & 1853 & -1279.04 \\
\hline $\mathrm{HB}(\mathrm{I})$ & $398 \pm 790$ & 1946 & -1150 \\
\hline $\mathrm{HB}(\mathrm{M}) \times 1.3$ & $-249 \pm 909$ & 1533 & -2030.64 \\
\hline $\mathrm{HB}(\mathrm{M}) \times 1.6$ & $-786 \pm 1048$ & 1268 & -2840.08 \\
\hline $\mathrm{HB}(\mathrm{I}) \times 1.3$ & $-105 \pm 878$ & 1616 & -1825.88 \\
\hline $\mathrm{HB}(\mathrm{I}) \times 1.6$ & $-609 \pm 993$ & 1337 & -2555.28 \\
\hline Owen (M) & $533 \pm 757$ & 2017 & -950 \\
\hline Owen (I) & $595 \pm 766$ & 2096 & -906 \\
\hline Owen $(\mathrm{M}) \times 1.3$ & $69 \pm 755$ & 1549 & -1410.8 \\
\hline Owen $(\mathrm{M}) \times 1.6$ & $-393 \pm 757$ & 1091 & -1876.72 \\
\hline Owen (I) x 1.3 & $151 \pm 761$ & 1643 & -1340.56 \\
\hline Owen (I) x 1.6 & $-1876 \pm 788$ & -332 & -3420.48 \\
\hline Mifflin SJ.(M) & $588 \pm 756$ & 2070 & -893.76 \\
\hline Mifflin SJ.(I) & $707 \pm 743$ & 2163 & -749.28 \\
\hline Mifflin SJ.(M) x 1.3 & $142 \pm 755$ & 1622 & -1337.8 \\
\hline Mifflin SJ.(M) x 1.6 & $-304 \pm 760$ & 1186 & -1793.6 \\
\hline Mifflin SJ.(I) x 1.3 & $295 \pm 734$ & 1734 & -1143.64 \\
\hline Mifflin SJ.(I) x 1.6 & $-115 \pm 727$ & 1310 & -1539.92 \\
\hline Iret.J.Ob.(M) & $202 \pm 1014$ & 2189 & -1785.44 \\
\hline Iret.J.Ob.(I) & $237 \pm 1012$ & 2221 & -1746.52 \\
\hline Iret.J.Ob.(M) x1.3 & $-402 \pm 820$ & 1205 & -2009.2 \\
\hline Iret.J.Ob.(M) x1.6 & $-974 \pm 918$ & 825 & -2773.28 \\
\hline Iret.J.Ob.(I) x1.3 & $-356 \pm 815$ & 1241 & -1953.4 \\
\hline Iret.J.Ob.(I) x1.6 & $-918 \pm 902$ & 850 & -2685.92 \\
\hline Iret.J.92(M) & $260 \pm 946$ & 2114 & -1594.16 \\
\hline Iret.J.92(I) & $291 \pm 957$ & 2167 & -1584.72 \\
\hline Iret.J.92(M) x1.3 & $-325 \pm 693$ & 1033 & -1683.28 \\
\hline Iret.J.92(M) x1.6 & $-880 \pm 688$ & 468 & -2228.48 \\
\hline Iret.J.92(I) x1.3 & $-286 \pm 706$ & 1098 & -1669.76 \\
\hline Iret.J.92(I) x1.6 & $-831 \pm 703$ & 547 & -2208.88 \\
\hline
\end{tabular}

HB: Harris-Benedict, MifflinSJ: Mifflin-St Joir 1990, Iret.J: Ireton-Jones, Ob:Obesity

M: Calculation with measured weight, I: Calculation with ideal weight 
Table 7. The frequencies of measured and calculate energy consumptions ratios

\begin{tabular}{|c|c|c|c|}
\hline Standart Formula & Insufficient (\%) & Sufficient (\%) & High (\%) \\
\hline $\mathrm{HB}(\mathrm{M})$ & 39.4 & 25.4 & 35.2 \\
\hline $\mathrm{HB}(\mathrm{I})$ & 46.5 & 29.8 & 23.9 \\
\hline $\mathrm{HB}(\mathrm{M}) \times 1.3$ & 23.9 & 18.3 & 57.7 \\
\hline $\mathrm{HB}(\mathrm{M}) \times 1.6$ & 14.1 & 21.1 & 64.8 \\
\hline $\mathrm{HB}(\mathrm{I}) \times 1.3$ & 29.6 & 21.1 & 49.3 \\
\hline $\mathrm{HB}(\mathrm{I}) \times 1.6$ & 14.1 & 21.1 & 64.8 \\
\hline Owen (M) & 52.1 & 36.6 & 11.3 \\
\hline Owen (I) & 57.7 & 29.6 & 12.7 \\
\hline Owen $(\mathrm{M}) \times 1.3$ & 22.5 & 40.8 & 36.6 \\
\hline Owen $(\mathrm{M}) \times 1.6$ & 11.3 & 25.4 & 63.4 \\
\hline Owen (I) x 1.3 & 23.9 & 46.5 & 29.6 \\
\hline Owen (I) x 1.6 & 1.4 & 2.8 & 95.8 \\
\hline Mifflin SJ.(M) & 56.3 & 29.6 & 14.1 \\
\hline Mifflin SJ.(I) & 66.2 & 25.4 & 8.5 \\
\hline Mifflin SJ.(M) x 1.3 & 29.8 & 35.2 & 35.2 \\
\hline Mifflin SJ.(M) x 1.6 & 14.1 & 23.9 & 62.0 \\
\hline Mifflin SJ.(I) x 1.3 & 29.6 & 43.7 & 26.8 \\
\hline Mifflin SJ.(I) x 1.6 & 18.3 & 25.4 & 56.3 \\
\hline Iret.J.Ob.(M) & 32.4 & 28.2 & 39.4 \\
\hline Iret.J.Ob.(I) & 35.2 & 29.6 & 35.2 \\
\hline Iret.J.Ob.(M) x1.3 & 15.5 & 21.1 & 63.4 \\
\hline Iret.J.Ob.(M) x1.6 & 8.5 & 14.1 & 77.5 \\
\hline Iret.J.Ob.(I) x1.3 & 16.9 & 19.7 & 63.4 \\
\hline Iret.J.Ob.(I) x1.6 & 7.0 & 14.1 & 78.9 \\
\hline Iret.J.92(M) & 26.8 & 43.7 & 29.6 \\
\hline Iret.J.92(I) & 31.0 & 42.3 & 26.8 \\
\hline Iret.J.92(M) x1.3 & 12.7 & 25.4 & 62.0 \\
\hline Iret.J.92(M) x1.6 & 4.2 & 12.7 & 83.1 \\
\hline Iret.J.92(I) x1.3 & 14.1 & 23.9 & 62.0 \\
\hline Iret.J.92(I) x1.6 & 4.2 & 12.7 & 83.1 \\
\hline
\end{tabular}

HB: Harris-Benedict, MifflinSJ: Mifflin-St Joir 1990, Iret.J: Ireton-Jones, Ob:Obesity M: Calculation with measured weight, I: Calculation with ideal weight 


\section{DISCUSSION}

We recorded the mean of energy consumption of patients being followed up on a mechanical ventilator in the internal medicine intensive care unit of a university hospital, with our metabolic monitors compatible with the indirect calorimeter method. We found the mean energy consumption as $2078 \pm 794$ $\mathrm{kcal} /$ day. According to the studies executed in the 1980 s, the average energy need of an intensive care patient was around 1700 to 2200 kilocalories ${ }^{20,21}$. Nevertheless, the mean energy consumption measured with 24-hour measurements in the current studies was reported as between 1562 and 2876 calories/day ${ }^{22,23}$.Cheng et al. reported in their study the average energy needs per kilogram of patients on mechanical ventilator as $24.5 \pm 8.6 \mathrm{kcal} / \mathrm{kg}^{24}$. In our study, we found the mean energy need per kilogram as $31.64 \pm 13.82 \mathrm{kcal} / \mathrm{kg}$. We think that this difference is due to demographic variability of patient groups. Walker et al. stated in their review published in 2009, that the predictive formulas were created according to specific patient groups. Due to the heterogeneity of intensive care patients, and rapidly changeable nature of their energy consumption levels, formulas developed in specific patient groups are often insufficient ${ }^{25}$.

The biggest disadvantage of energy measurement with indirect calorimeter was considered as time spent for a 24-hour measurement. Thus, in our study we compared the energy consumption values measured in the 2nd, 6th, 12th and at the end of the 24th hours, and found a strong correlation between them. In addition to this strong correlation, we found near midline distributions through Bland Altman analysis. Furthermore, adequacy rates showed us, that malnutrition or overfeeding was in most of the patients. Therefore, we considered that the measurements in 2 nd, 6 th or 12 th hour can be used in place of the 24-hour measurements. However, we thought, that waiting for the 24-hour measurement may give more accurate results and help patient management more. According to our review on previous literature, all studies were based on 24-hour measurements. Petros et al. showed in their study executed in 2001 on 46 intubated patients, that there was no significant difference between the measurements performed after a 5-minute stable period and after 30 minutes $^{26}$.

In our study, both predicted and ideal weights were used when calculating predictive equations. Studies have shown that higher accuracies can be achievable in predictive equations calculated with ideal or corrected weights ${ }^{27,28}$. We compared the compatibility of predictive formulas calculated with ideal and measured weights, and we found that the adequacy rates vary according to the use of the measured or ideal weights.

For the predictive equations, there is also a strategy to multiply the energy needs of the patients with correction factors, by considering the clinical conditions of the patients. However, there is no clear consensus on the increase level of energy needs in patients. According to the previous studies, the energy need in sepsis, trauma and surgery patients were increased up to $90 \%$ percent ${ }^{29,30}$. Similar to the study by MacDonald et al., we multiplied the calculated energy needs of patients with the factors of 1.3 and 1.6, and repeated the correlation analysis ${ }^{31}$. We found that this multiplication did not alter the correlation. None of the predictive equations were found to be compatible to cover all of the patients ${ }^{25,32}$.

Predictive equations are easily accessible and inexpensive techniques; however, these formulas were developed by studies on specific patient groups. For example, Harris-Benedict formula was developed in 1919 in a group of patients consisting of 136 men and 103 women $^{33}$. Since then, anthropometric data including weight and body mass index changed significantly. Haugen et al. emphasized the anthropometric changes in the American society, by stating that average lengths were stayed to be the same, whereas significant changes happened in weights and, thus in body mass index ${ }^{34}$. Reid et al. executed a study on trauma or postoperative patients on mechanical ventilation, whose energy consumption was measured with indirect calorimeter for 5 days. Similar to our study, they proportioned the MEC to CEC obtained from predictive formulas, and subdivided into three groups according to the energy intake of patients, namely insufficient, sufficient and overfed groups. They found that the energy needs of patients showing daily variations, cannot be determined by predictive equations ${ }^{35}$. Therefore, predictive equations may be insufficient in an intensive care patient whose energy needs may change at any time.

The researchers searched for alternative methods for indirect calorimeter. Flancbaum et al compared the indirect calorimeter with the Liggett formula, by using the Fick method in postoperative intensive care 
unit patients, and found a weak correlation ${ }^{29}$. They stated that the fluctuation in SVO2 was high due to the development of sepsis in the majority of patients, and tissue oxygenation was impaired momentarily. The researchers concluded, that the Fick method was a weak alternative to indirect calorimeter ${ }^{29,36}$. In our study, we used the indirect calorimeter technique as a non-invasive method. The Swan-Ganz catheter can be used for measuring of energy consumption only in patients who were catheterized for other reason.

There are many studies in the previous literature on whether energy needs of patients with higher mortality rates increase ${ }^{32,37}$. While Flancbaum et al. claimed a relationship between disease severity and energy consumption, Weissman et al. found weak correlations between these variables ${ }^{29,38}$. Nevertheless, Brandi et al. could not find any correlation between these variables ${ }^{39}$. Similarly, in our study we could not find any significant correlation between APACHE II, SOFA, SAPS II scores and MEC. In addition, we compared the energy consumption levels in patients fed via enteral, parenteral or combined ways, and we did not find any significant difference among these feeding types, which is similar to the results of Cheng et $\mathrm{al}^{24}$.

Frankelfield et al. found a correlation between inotropic therapy, inotropic treatment dose and energy consumption of the patients ${ }^{32}$. However, in our study we did not observe any association between MEC and inotropic therapy. This difference may be due to the differences of the patient populations of two studies. While our patient population were in the intensive care unit predominantly due to internal medicine pathologies, Frankelfield et al. followed the post-operative patients. Therefore, it may be useful to carry out more studies on this subject.

In our study, we examined the correlations between patients' procalcitonin, albumin, BNP, lactate, WBC, hematocrit and platelet values during admissions, and energy consumption. Except for a moderate correlation with WBC, no correlation was found between the other variables and MEC. According to our review, we did not find any similar studies in the previous literature, therefore we recommend more research focused on this research question. Previous studies demonstrated, that sepsis increases energy consumption ${ }^{40,41}$. Thus, the correlation between MEC and white blood cell count may be related to sepsis in these patients. Since alterations in thyroid functions can affect basal metabolic rate and energy consumption, hypothyroidism has an increased importance in intensive care patients compared to outpatients ${ }^{42,43}$. In our study, we found a weak negative correlation between TSH values and energy consumption. According our result, energy consumption may decrease with hypothyroidism. However, we think that further studies are needed to clarify this association. Furthermore, we compared the measured energy consumption among the groups with and without malnutrition, and found no significant difference among these groups.

The positive effects of correct calculation of energy consumption on deceasing mortality were frequently reported in the previous literature. According to these studies, even a few days of suboptimal nutrition causes weakening of the respiratory muscles. Adequate nutrition was significantly correlated inversely with ventilator dependence and intensive care hospitalization time. In a previous study, intensive care hospitalization times of sufficiently fed and undernourished patients were found as $39 \pm 20$ to $45 \pm 25$ days, respectively, and follow-up times on the ventilator were reported as $54 \pm 28$ and $65 \pm 48$ days, respectively,10. Proper nutrition reduces morbidity and mortality, and also shortens the length of hospitalization in intensive care units ${ }^{44,45}$.

Indirect calorimetry has become not only a "gold standard" but an "achievable gold standard" in determining energy consumption. In case where indirect calorimetry cannot be used, predictive equations are appropriate alternatives to use. MacDonald et al. suggested the determination of the energy need with predictive equations by avoiding malnutrition, and titration of this energy need value with an indirect calorimeter, which may be beneficial for the patients ${ }^{31}$.

Among the limitations of our study was patient homogeneity reflecting the characteristics of a tertiary healthcare center. Furthermore, this was a singlecenter study with limited sample size. A small change during patient follow-up can affect energy consumption. For this reason, measuring energy consumption at more frequent intervals could give more accurate results. In this study, we may have another limitation is not making measurements more frequently.

In conclusion, we recommend that the indirect calorimeter method should be used in intensive care patients to maintain nutrition properly. Nutrition therapy protocol should be individualized for each patient. Under conditions where indirect calorimeter 
cannot be used, or it is not desirable to wait for 24 hours; feeding can be started according to the results of a 2-hour measurement, or reliable predictive equations. We consider that the maintenance therapy should be organized according to the 24-hour measurement.

Yazar Katkıları: Çalışma konsepti/Tasarımı: EK, OT; Veri toplama: EK, OT, ME; Veri analizi ve yorumlama: EK, OT, ME; Yazı taslağı: EK, OT, ME; İçeriğin eleştirel incelenmesi: ME; Son onay ve sorumluluk: ME, EK, OT; Teknik ve malzeme desteği: EK, OT; Süpervizyon: EK, OT, ME; Fon sağlama (mevcut ise): yok.

Etik Onay: Bu çalısma için Cukurova Üniversitesi Tip Fakültes Girişimsel Olmayan Klinik Araştırmalar Etik Kurulundan 03.01.2014 tarih ve $27 / 2$ sayll kararı ile etik onay alınmıştır.

Hakem Değerlendirmesi: Dış bağımsız.

Çıkar Çatışması: Yazarlar çıkar çatışması beyan etmemişlerdir. Finansal Destek: Yazarlar finansal destek beyan etmemislerdir.

Author Contributions: Concept/Design : EK, OT; Data acquisition: EK, OT, ME; Data analysis and interpretation: EK, OT, ME; Drafting manuscript: EK, OT, ME; Critical revision of manuscript: ME; Final approval and accountability: ME, EK, OT; Technical or material support: EK, OT; Supervision: EK, OT, ME; Securing funding (if available): $\mathrm{n} / \mathrm{a}$.

Ethical Approval: Ethical approval was obtained for this study from the Non-Invasive Clinical Research Ethics Committee of Cukurova University Faculty of Medicine with the decision dated 03.01.2014 and numbered 27/2.

Peer-review: Externally peer-reviewed.

Conflict of Interest: Authors declared no conflict of interest.

Financial Disclosure: Authors declared no financial support

\section{REFERENCES}

1. Cerra FB, Benitez MR, Blackburn GL, Irwin RS, Jeejeebhoy K, Katz DP, et al. Applied nutrition in ICU patients: a consensus statement of the American College of Chest Physicians. Chest. 1997;111:769-78.

2. Pirat A, Tucker AM, Taylor KA, Jinnah R, Finch CG, Nates JL. Comparison of measured versus predicted energy requirements in critically ill cancer patients. Respir Care. 2009;54:487-94.

3. Heyland DK, Dhaliwal R, Day A, Jain M, Drover J. Validation of the Canadian clinical practice guidelines for nutrition support in mechanically ventilated, critically ill adult patients: results of a prospective observational study. Crit Care Med. 2004;32:2260-6.

4. Heyland D. Nutritional support in the critically ill patient: a critical review of the evidence. Crit Care Clin. 1998;14:423-40.

5. Klein S, Kinney J, Jeejeebhoy K, Alpers D, Hellerstein M, Murray M, et al. Nutrition support in clinical practice: review of published data and recommendations for future research directions. Summary of a conference sponsored by the National Institutes of Health, American Society for Parenteral and Enteral Nutrition, and American Society for Clinical Nutrition. Am J Clin Nutr. 1997;66:683-706.

6. Wong PW, Enriquez A, Barrera R. Nutritional support in critically ill patients with cancer. Crit Care Clin. 2001;17:743-67.
7. Klein CJ, Stanek GS, WILES III CE. Overfeeding macronutrients to critically ill adults: metabolic complications. J Am Diet Assoc. 1998;98:795-806.

8. Mechanick JI, Brett EM. Nutrition and the chronically critically ill patient. Curr Opin Clin Nutr Metab Care. 2005;8:33-9.

9. Fung EB. Estimating energy expenditure in critically ill adults and children. AACN Clin Issues. 2000;11:480-97.

10. Walker RN, Heuberger RA. Predictive equations for energy needs for the critically ill. Respir Care. 2009;54:509-21.

11. Faisy C, Guerot E, Diehl J-L, Labrousse J, Fagon J-Y. Assessment of resting energy expenditure in mechanically ventilated patients. Am J Clin Nutr. 2003;78:241-9.

12. Frankenfield D, Smith JS, Cooney RN. Validation of 2 approaches to predicting resting metabolic rate in critically ill patients. JPEN J Parenter Enteral Nutr. 2004;28:259-64.

13. Robinson JD, Lupkiewicz SM, Palenik L, Lopez LM, Ariet M. Determination of ideal body weight for drug dosage calculations. Am J Hosp Pharm. 1983;40:10169 .

14. Heart N, Lung, Institute B, Diabetes NIo, Digestive, Diseases K. Clinical guidelines on the identification, evaluation, and treatment of overweight and obesity in adults: the evidence report: National Heart, Lung, and Blood Institute; 1998.

15. Prentice AM, Jebb SA. Beyond body mass index. Obes Rev. 2001;2:141-7.

16. Pai MP, Paloucek FP. The origin of the "ideal" body weight equations. Ann Pharmacother. 2000;34:10669.

17. Singer P, Berger MM, Van den Berghe G, Biolo G, Calder P, Forbes A, et al. ESPEN guidelines on parenteral nutrition: intensive care. Clin Nutr. 2009;28:387-400.

18. Bland JM, Altman DG. Measuring agreement in method comparison studies. Stat Methods Med Res. 1999;8:135-60.

19. Swinamer DL, Phang PT, Jones RL, Grace M, King EG. Twenty-four hour energy expenditure in critically ill patients. Crit Care Med. 1987;15:637-43.

20. Bursztein S, Saphar P, Singer P, Elwyn DH. A mathematical analysis of indirect calorimetry measurements in acutely ill patients. Am J Clin Nutr. 1989;50:227-30.

21. Van Lanschot J, Feenstra B, Vermeij CG, Bruining HA. Calculation versus measurement of total energy expenditure. Crit Care Med. 1986;14:981-5.

22. Graf S, Karsegard VL, Viatte V, Heidegger CP, Fleury Y, Pichard C, et al. Evaluation of three indirect calorimetry devices in mechanically ventilated patients: which device compares best with the Deltatrac IIß? A prospective observational study. Clin Nutr. 2015;34:60-5. 
23. Sundström M, Tjäder I, Rooyackers $\mathrm{O}$, Wernerman J. Indirect calorimetry in mechanically ventilated patients. A systematic comparison of three instruments. Clin Nutr. 2013;32:118-21.

24. Cheng $\mathrm{CH}$, Chen $\mathrm{CH}$, Wong $\mathrm{Y}$, Lee BJ, Kan MN, Huang YC. Measured versus estimated energy expenditure in mechanically ventilated critically iII patients. Clin Nutr. 2002;21:165-72.

25. Maday K. Energy estimation in the critically ill: a literature review. Universal Journal of Clinical Medicine. 2013;1:39-43.

26. Petros S, Engelmann L. Validity of an abbreviated indirect calorimetry protocol for measurement of resting energy expenditure in mechanically ventilated and spontaneously breathing critically ill patients. Intensive Care Med. 2001;27:1164-8.

27. Ahmad A, Duerksen DR, Munroe S, Bistrian BR. An evaluation of resting energy expenditure in hospitalized, severely underweight patients. Nutrition. 1999;15:384-8.

28. Cutts ME, Dowdy RP, Ellersieck MR, Edes TE. Predicting energy needs in ventilator-dependent critically ill patients: effect of adjusting weight for edema or adiposity. Am J Clin Nutr. 1997;66:1250-6.

29. Flancbaum L, Choban PS, Sambucco S, Verducci J, Burge JC. Comparison of indirect calorimetry, the Fick method, and prediction equations in estimating the energy requirements of critically ill patients. Am J Clin Nutr. 1999;69:461-6.

30. Kross EK, Sena M, Schmidt K, Stapleton RD. A comparison of predictive equations of energy expenditure and measured energy expenditure in critically ill patients. J Crit Care. 2012;27:321. e5-. e12.

31. MacDonald A, Hildebrandt L. Comparison of formulaic equations to determine energy expenditure in the critically ill patient. Nutrition. 2003;19:233-9.

32. Frankenfield DC, Oniert LA, Badellino MM, Wiles III CE, Bagley SM, Goodarzi S et al. Correlation between measured energy expenditure and clinically obtained variables in trauma and sepsis patients. JPEN J Parenter Enteral Nutr. 1994;18:398-403.

33. Harris JA, Benedict FG. A biometric study of human basal metabolism. Proc Natl Acad Sci U S A. 1918;4:370-3.

34. Haugen HA, Chan LN, Li F. Indirect calorimetry: a practical guide for clinicians. Nutr Clin Pract. 2007;22:377-88.
35. Reid CL. Poor agreement between continuous measurements of energy expenditure and routinely used prediction equations in intensive care unit patients. Clin Nutr. 2007;26:649-57.

36. Spears KE, Kim H, Behall KM, Conway JM. Handheld indirect calorimeter offers advantages compared with prediction equations, in a group of overweight women, to determine resting energy expenditures and estimated total energy expenditures during research screening. J Am Diet Assoc. 2009;109:836-45.

37. Rodriguez DJ, Sandoval W, Clevenger FW. Is measured energy expenditure correlated to injury severity score in major trauma patients? J Surg Res. 1995;59:455-9.

38. Weissman C, Sardar A, Kemper M. An in vitro evaluation of an instrument designed to measure oxygen consumption and carbon dioxide production during mechanical ventilation. Crit Care Med. 1994;22:1995-200.

39. Brandi LS, Santini L, Bertolini R, Malacarne P, Casagli S, Baraglia AM. Energy expenditure and severity of injury and illness indices in multiple trauma patients. Crit Care Med. 1999;27:2684-9.

40. Cunningham JJ. Factors contributing to increased energy expenditure in thermal injury: a review of studies employing indirect calorimetry. JPEN J Parenter Enteral Nutr. 1990;14:649-56.

41. Bessey PQ, Watters JM, Aoki TT, Wilmore DW. Combined hormonal infusion simulates the metabolic response to injury. Ann Surg. 1984;200:264.

42. Kim B. Thyroid hormone as a determinant of energy expenditure and the basal metabolic rate. Thyroid. 2008;18:141-4.

43. Wang F, Pan W, Wang H, Wang S, Pan S, Ge J. Relationship between thyroid function and ICU mortality: a prospective observation study. Crit Care. 2012;16:1-9.

44. Rubinson L, Diette GB, Song X, Brower RG, Krishnan JA. Low caloric intake is associated with nosocomial bloodstream infections in patients in the medical intensive care unit. Crit Care Med. 2004;32:350-7.

45. Heyland DK, Schroter-Noppe D, Drover JW, Jain M, Keefe L, Dhaliwal R et al. Nutrition support in the critical care setting: current practice in canadian ICUs-opportunities for improvement? JPEN J Parenter Enteral Nutr. 2003;27:74-83. 